\title{
Effects of Fish on Emergent Insect-Mediated Flux of Methyl Mercury across a Gradient of Contamination
}

\author{
Brent N. Tweedy, ${ }^{\dagger}$ Ray W. Drenner, ${ }^{\dagger}$ Matthew M. Chumchal, ${ }^{*}{ }^{\dagger}$ and James H. Kennedy ${ }^{\ddagger}$ \\ ${ }^{\dagger}$ Department of Biology, Texas Christian University, Winton Scott Room 401, 2800 South University Drive, Fort Worth, Texas \\ 76129, United States \\ ${ }^{\ddagger}$ Department of Biology, University of North Texas, 1155 Union Circle No. 310559, Denton, Texas 76203, United States
}

Supporting Information

ABSTRACT: We examined the effects of fish predation on emergent insect-mediated methyl mercury ( $\mathrm{MeHg}$ ) flux across a gradient of $\mathrm{MeHg}$ contamination in experimental ponds. Emergent insects were collected from ponds with $(n=5)$ and without fish $(n=5)$ over a six week period using floating emergence traps. We found that the potential for $\mathrm{MeHg}$ flux increased with $\mathrm{Hg}$ contamination levels of the ponds but that the realized $\mathrm{MeHg}$ flux of individual insect taxa was determined by fish presence. Fish acted as size-selective predators and reduced $\mathrm{MeHg}$ flux by suppressing emergence of large insect taxa (dragonflies and damselflies) but not small insect taxa (chironomids and microcaddisflies). MeHg flux by small insect taxa was correlated with concentrations of $\mathrm{MeHg}$ in terrestrial spiders along the shorelines of the study ponds, demonstrating for the first time the cross-system transport of $\mathrm{MeHg}$ by emergent insects to a terrestrial spider.

\section{INTRODUCTION}

The fate and transfer of the methylated form of $\mathrm{Hg}(\mathrm{MeHg})$ in the environment is of particular concern to ecotoxicologists because $\mathrm{MeHg}$ readily bioaccumulates in the tissues of biota and is extremely toxic, negatively affecting the health of wildlife. ${ }^{1}$ Worldwide anthropogenic emissions of inorganic forms of $\mathrm{Hg}$ coupled with a dynamic, global atmospheric cycle have resulted in contamination of most ecosystems on Earth with levels of $\mathrm{Hg}$ that exceed preindustrial baselines. ${ }^{2}$ Because the conversion of inorganic forms of $\mathrm{Hg}$ to $\mathrm{MeHg}$ is a process primarily mediated by aquatic microbes, ${ }^{2} \mathrm{MeHg}$ was previously thought to only threaten aquatic biota and consumers of aquatic organisms. However, recent studies have found elevated concentrations of $\mathrm{MeHg}$ in terrestrial consumers. ${ }^{3-6}$

Contaminants, such as $\mathrm{MeHg}$, that enter aquatic food webs have the potential to be transferred to terrestrial food webs when aquatic insects that spend part of their life cycle in aquatic ecosystems emerge as adults. ${ }^{6-10}$ Although it is recognized that emergent aquatic insects provide critical energy subsidies to terrestrial food webs adjacent to aquatic systems, ${ }^{1-16}$ their role as biovectors of aquatic contaminants to terrestrial ecosystems is just beginning to be understood. ${ }^{6-9,17}$ Factors that control the magnitude of insect-mediated $\mathrm{MeHg}$ flux have rarely been studied, ${ }^{18}$ and the relationship between insect-mediated $\mathrm{MeHg}$ flux and $\mathrm{MeHg}$ concentration in terrestrial predators has not been examined.

In this study, we assess insect-mediated $\mathrm{MeHg}$ flux across a gradient of $\mathrm{Hg}$ contamination and determine how $\mathrm{MeHg}$ flux is affected by fish predation. We hypothesized that fish predation can reduce insect-mediated contaminant flux out of aquatic

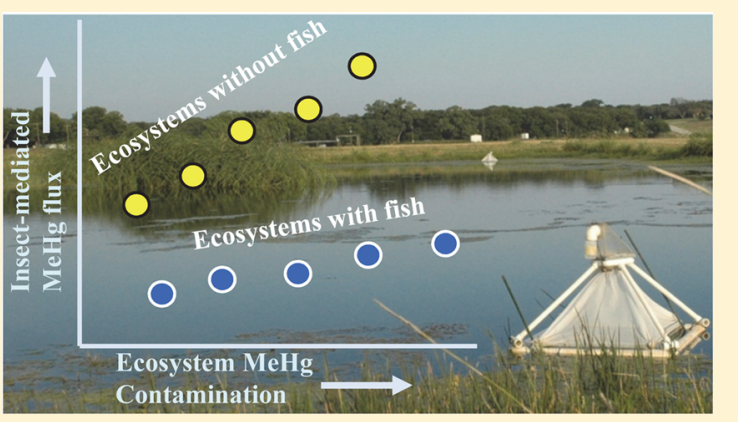

ecosystems by reducing aquatic insect biomass and altering insect community structure. ${ }^{18-23}$ Here, we use experimental pond ecosystems to test two hypotheses: $\left(\mathrm{H}_{1}\right)$ the potential for insect-mediated $\mathrm{MeHg}$ flux from waterbodies is positively related to the overall level of food web contamination, but the realized $\mathrm{MeHg}$ flux is regulated by fish predation on emergent aquatic insects; and $\left(\mathrm{H}_{2}\right)$ the $\mathrm{MeHg}$ flux of emerging insects is correlated with $\mathrm{MeHg}$ concentrations in terrestrial long-jawed orb weaver spiders (Tetragnathidae: Tetragnatha sp.). Spiders that live on the shorelines of aquatic ecosystems are predators of aquatic insects ${ }^{7-9,24-27}$ and play a key role in mediating contaminant flux from aquatic to terrestrial ecosystems because they are themselves consumed by terrestrial predators such as birds. ${ }^{4,8}$

\section{METHODS}

Study Site. We conducted the present study in 10 experimental ponds in Fort Worth, Texas, USA. The experimental ponds are whole ecosystems with earthen bottoms that contain complex communities of macrophytes, benthic invertebrates, and herptiles. Ponds are large and range in size from 0.23 to 0.54 ha with maximum and average depths of 1.2 and $0.6 \mathrm{~m}$, respectively. Macrophyte communities were variable between ponds and were composed of several species of emergent and submerged taxa. An image from the

Received: August 16, 2012

Revised: December 21, 2012

Accepted: January 3, 2013

Published: January 3, 2013 
experimental pond facility (Figure S1, Supporting Information) and a summary of vegetation and nutrient data for each pond (Table S1, Supporting Information) can be found in the Supporting Information. In this study, we did not add $\mathrm{Hg}$ to the experimental ponds. Pilot studies revealed that the ponds had food chains contaminated with $\mathrm{Hg}$, presumably from atmospheric deposition to the pond surfaces and the watershed of a nearby reservoir, Eagle Mountain Lake, which is the source of water to the ponds. Ponds were constructed in the 1930s and 1950 s, and there is no historical data that can be used to assess why ponds varied in their level of $\mathrm{Hg}$ contamination.

Experimental Design. In 2009, we filled ponds with water from Eagle Mountain Lake, and ponds were randomly assigned to one of two treatments: ponds without fish $(n=5)$ and ponds with fish $(n=5)$. In June 2010, we purchased fish from a commercial hatchery and stocked the ponds in the fish treatment with juvenile largemouth bass (Centrachidae: Micropterus salmoides) and bluegill (Centrachidae: Lepomis macrochirus) at a density of 125 and 889 individuals per hectare, respectively. Visual observation and seining at the end of the study indicated that bluegill and largemouth bass had spawned in all but one of the ponds, where only bluegill had survived and spawned. Largemouth bass and bluegill are commonly found in fish communities throughout the United States. ${ }^{28}$ Centrarchids visually locate and preferentially attack large prey items. $^{29,30}$ Bluegill and largemouth bass feed on benthic invertebrates as well as other prey. ${ }^{31-34}$

Experimental Procedures. Emergent insects were collected over a continuous six week period beginning in May 2011. We used pyramid-shaped floating emergence traps to sample adult emerging insects (Figure S2, Supporting Information). Each trap sampled a $0.53 \mathrm{~m} \times 0.53 \mathrm{~m}$ area $\left(0.28 \mathrm{~m}^{2}\right)$. Four traps were deployed in each pond. Each trap was held in place with two $1 \mathrm{~cm}$ diameter plastic-coated stakes (Figure S2, Supporting Information) pushed into the sediment by hand. Traps were staked at random locations near each corner of the pond at an average water depth of $49 \pm 0.97$ (average \pm standard error $(\mathrm{SE})$ ) $\mathrm{cm}$. The traps funneled emerging insects (chironomids, microcaddisflies, and 20\% of the damselflies) into a collecting bottle containing $85 \%$ denatured ethanol. Collecting bottles were replaced, and traps were moved to new locations each week. All dragonflies and $80 \%$ of damselflies did not move into the sampling bottle and were captured by hand from the lower part of the trap, placed on ice, and then frozen at $-20{ }^{\circ} \mathrm{C}$ in the lab. Nine percent of the total trapping effort was excluded from the study because traps were colonized by long-jawed orb weavers or damaged by wind.

Five taxonomic groups of insects accounted for the majority of emergence and are the focus of this study. Predatory taxa included dragonflies (Odonata:Anisoptera), damselflies (Odonata:Zygoptera), and predatory chironomids (Chironomidae: Tanypodinae). Herbivorous taxa included microcaddisflies (Trichoptera:Hydroptilidae) and herbivorous chironomids (Chironomidae:Chironominae and Chironomidae:Orthocladiinae). We collected an average of $3734 \pm 483$ (average \pm SE) individual insects from each pond (Table S2, Supporting Information). All individuals of each taxa collected from a given pond were counted and then pooled into a single composite sample for each taxa in each pond. All pooled samples were dried at $60{ }^{\circ} \mathrm{C}$ for $72 \mathrm{~h}$ and weighed to determine biomass. Emergence biomass is expressed as grams per meters squared per day.
To examine the relationship between $\mathrm{MeHg}$ contamination in a terrestrial consumer to $\mathrm{MeHg}$ flux from the ponds, we collected long-jawed orb weaver spiders along the shorelines of the ponds. Long-jawed orb weavers are obligate shoreline species that specialize in consumption of aquatic insects. ${ }^{7-9,24-27}$ At our study site, we frequently observed webs of long-jawed orb weavers containing small emergent insects. We collected spiders on June 2 and June 16 from the emergent vegetation along the edge of the ponds using sweep nets. On each date, two samples were collected from two corners of each pond that yielded $99.5 \pm 36.6$ (average \pm SE) long-jawed orb weavers per pond. Spiders were preserved in $85 \%$ denatured ethanol, pooled by pond, and dried at $60{ }^{\circ} \mathrm{C}$ for $72 \mathrm{~h}$.

MeHg Analysis. Prior to $\mathrm{MeHg}$ analysis, emergent insects and spider composite samples were homogenized to a fine powder using a clean mortar and pestle or ball-mill grinder. A single subsample from each composite sample was analyzed for $\mathrm{MeHg}$ at the Dartmouth College Trace Element Analysis Core Lab using a MERX automated MeHg system (Brooks Rand, Seattle, WA) interfaced with an Agilent $7500 \mathrm{c}$ inductively coupled plasma-mass spectrometer. ${ }^{35,36}$ Samples of a certified reference material (NIST Mussel 2976) were within certified ranges. A detailed description of $\mathrm{MeHg}$ analytical methods and $\mathrm{QA} \backslash \mathrm{QC}$ procedures is available in the Supporting Information. All $\mathrm{MeHg}$ concentration data is presented as nanograms per gram of dry weight. We estimated $\mathrm{MeHg}$ flux for each taxa over the course of the experiment by multiplying the total emergent biomass of each taxa by the concentration of $\mathrm{MeHg}$ in their tissues.

We used $\mathrm{MeHg}$ concentrations in herbivorous chironomids as a proxy for baseline $\mathrm{MeHg}$ contamination of the food web. $\mathrm{MeHg}$ concentrations in emergent dipterans have been shown previously to to be indicative of the level of ecosystem contamination. $^{37}$ In this study, $\mathrm{MeHg}$ concentrations in herbivorous chironomids were positively correlated with $\mathrm{MeHg}$ in other insect taxa (Figure S3, Supporting Information), confirming that herbivorous chironomids are appropriate indicators of baseline foodweb contamination by $\mathrm{MeHg}$.

Statistical Analysis. We used a series of analysis of covariance (ANCOVA; SPSS, Ver 20.0.0) models to determine the effect of $\mathrm{MeHg}$ concentrations in herbivorous chironomids (a proxy for overall level of $\mathrm{MeHg}$ contamination of the food web) (covariate) and fish presence (categorical variable) on total and taxa-specific MeHg flux (dependent variable). We first tested for an interaction effect between $\mathrm{MeHg}$ concentration in herbivorous chironomids and fish. If the interaction was not significant (an indication of homogeneous slopes and an assumption of ANCOVA), then the term was removed from the model to assess main effects of fish presence and $\mathrm{MeHg}$ concentration in herbivorous chironomids. If the interaction term was significant (indicating heterogeneous slopes), then we tested for an effect of fish at the average of the covariate and used this statistic to assess the effect of fish on the dependent variable. We used ANCOVA (using the same procedure as above) and linear regression to examine the relationship between $\mathrm{MeHg}$ concentrations in long-jawed orb weavers, fish presence and absence, and emergent insect $\mathrm{MeHg}$ flux. Data met assumptions of normality and homogeneity of variance. Statistical significance for all analyses was inferred at $P<0.05$.

\section{RESULTS}

Total MeHg flux, computed as the combined $\mathrm{MeHg}$ flux for the five insect taxa examined in this study, was positively and 

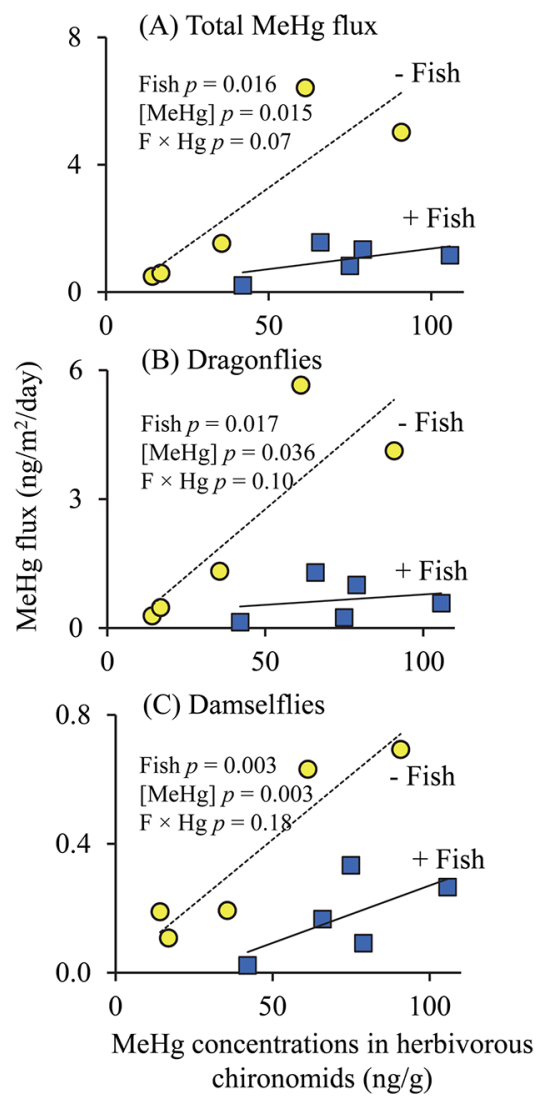
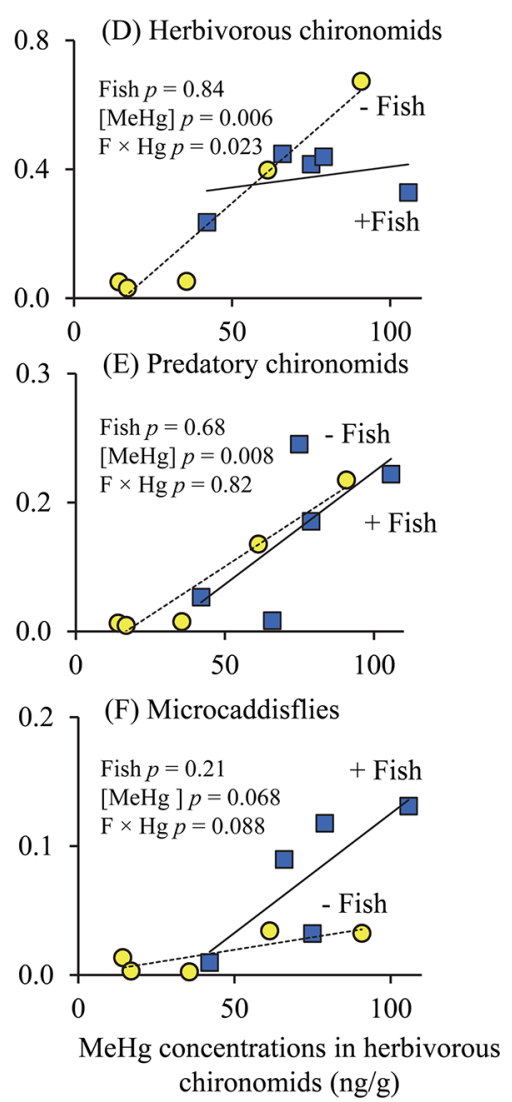

Figure 1. Relationship between herbivorous chironomid $\mathrm{MeHg}$ concentration (a proxy for baseline $\mathrm{MeHg}$ concentration) and $\mathrm{MeHg}$ flux for (A) all taxa, (B) dragonflies, (C) damselflies, (D) herbivorous chironomids, (E) predatory chironomids, and (F) microcaddisflies in ponds with and without fish. Solid lines with blue squares represent ponds with fish (+ Fish) and dashed lines with yellow circles represent ponds without fish ( - Fish). $P$ values from an ANCOVA testing for the main effects of chironomid $\mathrm{MeHg}$ concentration $([\mathrm{MeHg}])$ and fish presence (fish) and their interaction (F $\times \mathrm{Hg}$ ) on $\mathrm{MeHg}$ flux are included in each panel. The assumption of heterogeneous slopes was violated in the case of herbivorous chironomids; therefore, we report the treatment effect of fish at the average of the covariate. Complete ANCOVA statistics $(P$ values, $F$ statistics, and degrees of freedom) are reported in Table S3 in the Supporting Information. Note the scale of the $y$ axis differs for each taxa.

significantly related to $\mathrm{Hg}$ concentrations in herbivorous chironomids with the total $\mathrm{MeHg}$ flux significantly suppressed in ponds with fish (Figure 1A). For each insect taxa except microcaddisflies, $\mathrm{MeHg}$ flux was positively and significantly related to $\mathrm{MeHg}$ concentrations in herbivorous chironomids (Figure 1B-E). MeHg flux of large taxa, dragonflies and damselflies, was suppressed in ponds with fish (Figure 1B,C). The $\mathrm{MeHg}$ flux of small taxa, herbivorous and predatory chironomids and microcaddisflies, was not significantly affected by fish presence (Figure 1D-F). These results indicate that the reduction of total $\mathrm{MeHg}$ flux in ponds with fish can be explained by the reduction of flux from large taxa, dragonflies and damselflies. The effect of fish on $\mathrm{MeHg}$ flux was achieved through the suppression of emergent biomass of dragonflies and damselflies and not alteration of $\mathrm{MeHg}$ concentrations (Figures S4 and S5, Supporting Information).

The difference in total $\mathrm{MeHg}$ flux between ponds with and without fish was greatest in ponds with high $\mathrm{MeHg}$ concentrations in herbivorous chironomids (Figure 1A). This pattern in total $\mathrm{MeHg}$ flux mirrors the pattern in dragonflies because dragonflies accounted for the largest component of $\mathrm{MeHg}$ flux in ponds with and without fish $(73 \pm 13 \%$ and $42 \pm$ $18 \%$ (average \pm SE), respectively; Figure 1B). Damselflies exhibited a similar but less pronounced pattern. However, damselflies only accounted for $12.6 \pm 9.5 \%$ and $17.1 \pm 10.2 \%$ of the total $\mathrm{MeHg}$ flux in ponds with and without fish, respectively (Figure 1C). Small insects, which were not impacted by fish, did not exhibit the pattern of diverging slopes across the $\mathrm{MeHg}$ contamination gradient observed in the larger taxa (Figure 1D-F). For total insect and dragonfly $\mathrm{MeHg}$ flux, but not damselfly $\mathrm{MeHg}$ flux, the $\mathrm{MeHg}$ concentration in herbivorous chironomids $\times$ fish interactions were almost significantly different between ponds with and without fish across the $\mathrm{MeHg}$ gradient (Figure 1B). These marginally significant interactions should be interpreted with caution but ignoring them risks a type II error because of the small number of ponds in the study and the limited statistical power to detect interaction effects. ${ }^{38}$

$\mathrm{MeHg}$ contamination of long-jawed orb weavers collected along the shorelines of the ponds was significantly and positively correlated with the $\mathrm{MeHg}$ flux of small insect taxa (the sum of predatory and herbivorous chironomids and microcaddisflies) but was not significantly affected by fish (ANCOVA; $F_{1,7}=2.2 ; P=0.18$; Figure 2). This relationship presumably results from spider predation on small emergent insect taxa and is consistent with our observation of small insects trapped in the webs of long-jawed orb weavers along the shorelines of the study ponds. $\mathrm{MeHg}$ concentrations of longjawed orb weavers were not significantly correlated with the $\mathrm{MeHg}$ flux of large insect taxa (dragonflies and damselflies) (Figure S6, Supporting Information), and we never observed these large taxa trapped in spider webs. 


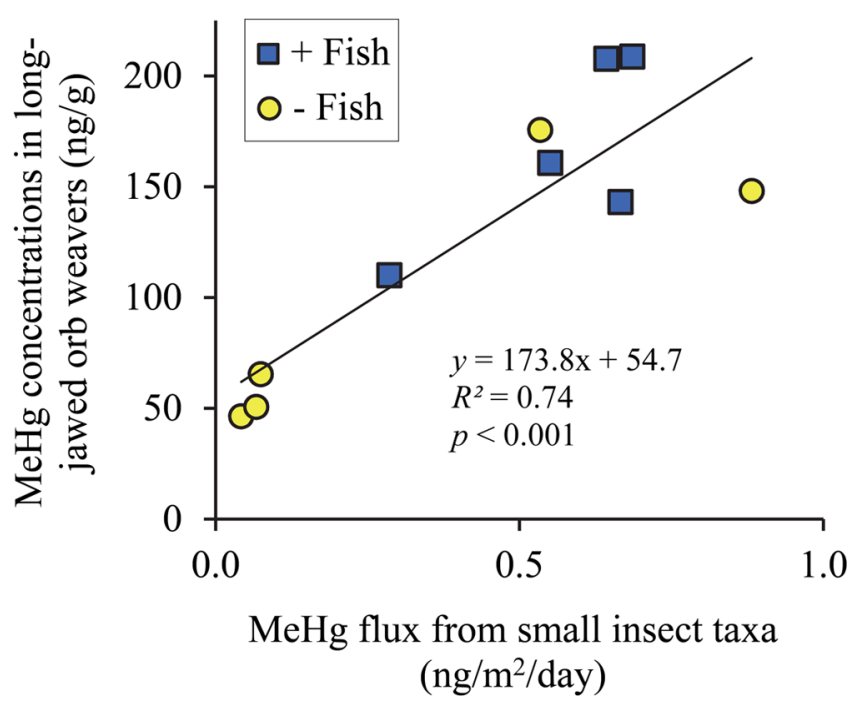

Figure 2. Relationship between $\mathrm{MeHg}$ flux in small insect taxa (herbivorous and predatory chironomids and microcaddisflies) and $\mathrm{MeHg}$ concentrations in long-jawed orb weaver spiders. Blue squares represent ponds with fish (+ Fish) and yellow circles ponds without fish (- Fish).

\section{DISCUSSION}

Our study indicates that the level of $\mathrm{MeHg}$ contamination of the food chain sets the potential for $\mathrm{MeHg}$ flux in emergent aquatic insects. In most aquatic ecosytems, the source of $\mathrm{MeHg}$ is inorganic $\mathrm{Hg}$ deposited from the atmosphere directly on the water body or its watershed and then converted to $\mathrm{MeHg}$ by microorganisms. ${ }^{2}$ Previous studies have shown a relationship between atmospheric deposition and $\mathrm{Hg}$ contamination of biota. ${ }^{37,39,40}$ Therefore, potential $\mathrm{MeHg}$ flux in aquatic insects would be expected to be correlated with atmospheric deposition of $\mathrm{Hg}$. Mercury deposition and the conversion of inorganic $\mathrm{Hg}$ to $\mathrm{MeHg}$ vary widely across the landscape due to complex interactions between regional $\mathrm{Hg}$ emissions, atmospheric processes and landcover that make some ecosystems sensitive to $\mathrm{Hg}$ inputs. ${ }^{2,41-43}$ Therefore, we would expect considerable variation in $\mathrm{MeHg}$ flux in aquatic insects and the transfer of $\mathrm{MeHg}$ to terrestrial food chains across large geographic areas.

In this study, we also show that, for a given level of $\mathrm{MeHg}$ contamination, the quantitative and qualitative nature of the flux of $\mathrm{MeHg}$ in aquatic insects can be regulated by the presence and absence of fish. Compared to ponds without fish, ponds with fish had lower $\mathrm{MeHg}$ flux from large-bodied insects such as odonates, which are vulnerable to fish predation, while fish did not effect $\mathrm{MeHg}$ flux from smaller-bodied insects such as chironomids, which are less vulnerable to predation. ${ }^{44,45}$ The net effect of fish was a reduction in total $\mathrm{MeHg}$ flux of up to a factor of 5 in the most $\mathrm{Hg}$-contaminated ponds. Therefore, we hypothesize that a combination of fish predation and prey vulnerability determines the realized $\mathrm{MeHg}$ flux across a gradient of $\mathrm{MeHg}$ contamination (Figure 3). Aquatic insect taxa differ in their vulnerability to fish predation. The $\mathrm{MeHg}$ flux for invulnerable prey will be the same in ponds with and without fish. The $\mathrm{MeHg}$ flux for vulnerable prey will be suppressed by fish, and the magnitude of suppression will be greatest in ponds with high levels of $\mathrm{MeHg}$ contamination.

Our study is one of the first linking $\mathrm{MeHg}$ flux in emerging insects to a terrestrial spider, the long-jawed orb weaver. We

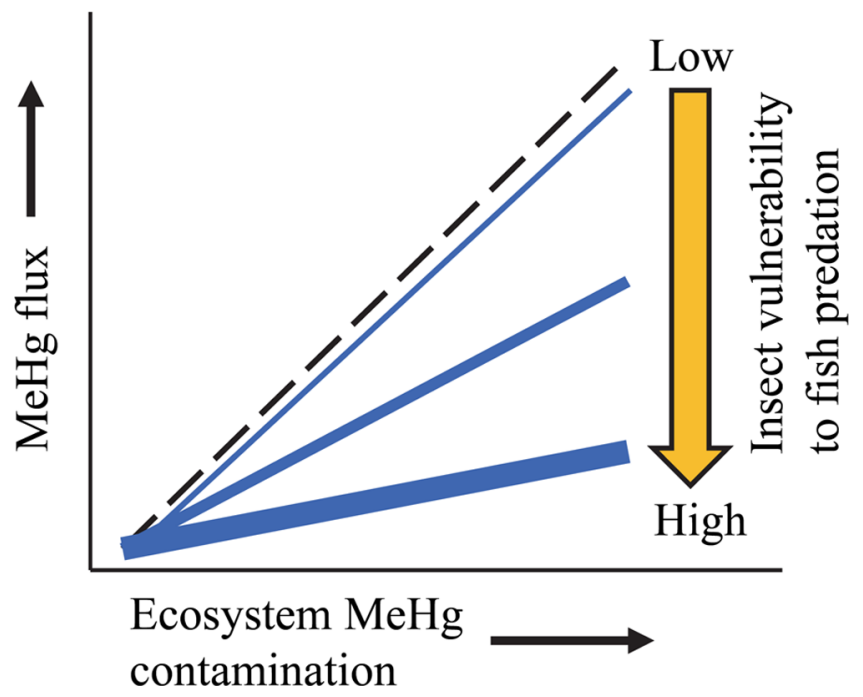

Figure 3. Potential patterns of mercury flux out of water bodies and into the terrestrial environment along a $\mathrm{MeHg}$ gradient in ecosystems with and without fish. This hypothetical plot illustrates the range of possible effects of fish on realized $\mathrm{MeHg}$ flux for a given insect taxon. A positive correlation of $\mathrm{MeHg}$ flux with increasing levels of mercury contamination is expected in ponds without fish (dashed line). A positive correlation between $\mathrm{MeHg}$ flux and $\mathrm{Hg}$ contamination is also expected in ponds with fish (solid lines), but the slope of the relationship is determined by vulnerability of the insect taxon to fish predation. Increasing line thickness indicates increasing vulnerability of the insect taxon to fish predation. Vulnerability is determined by complex ecological interactions between characteristics of the prey (e.g., body size and activity level), predator (e.g., feeding selectivity), and habitat (e.g., aquatic plant density). ${ }^{44,45}$ Although not shown in this figure or observed in our study, it is possible that small insect taxa not vulnerable to fish predation may be indirectly enhanced by fish if insect predators are suppressed by fish. ${ }^{44,45}$

found $\mathrm{MeHg}$ concentrations in long-jawed orb weavers were highly correlated with the $\mathrm{MeHg}$ flux of small insect taxa. Spider $\mathrm{MeHg}$ concentrations were not correlated with the $\mathrm{MeHg}$ flux in large insect taxa. Fish presence had no effect on the spider $\mathrm{Hg}$ contamination because fish primarily impact large insect taxa (such as dragonflies and damselflies) not consumed by long-jawed orb weavers. ${ }^{23}$ These results support the concept that contaminant monitoring programs could use shoreline spiders as biological monitors of aquatic pollution. ${ }^{7,8}$ Longjawed orb weavers could be used as biosentinels of $\mathrm{MeHg}$ concentrations in small emergent insect taxa and thus an indicator of the overall level of food web contamination.

In conclusion, this study demonstrates the combined influence of aquatic pollution and community structure on the cross-system transport of contaminants out of ponds to terrestrial consumers. Small $\left(<1 \mathrm{~km}^{2}\right)$ ponds and lakes, where the processes examined in this study are likely to be important, represent the numerically dominant lentic ecosystem covering more surface area than large lakes worldwide. ${ }^{46,47}$ The species richness of aquatic birds, plants, amphibians, and invertebrates is often relatively high in small, shallow, isolated lakes. ${ }^{46,48}$ However, the benefits to biodiversity provided by small ponds and lakes may be partially offset by the production and transport of $\mathrm{MeHg}$ to surrounding terrestrial food chains and wildlife. Although some small ponds are semipermanent and are naturally colonized or stocked with fish, others periodically dry or experience winter oxygen stress and do not contain fish. ${ }^{45,49}$ Compared to ponds with fish, ponds without fish will 
have a greater total $\mathrm{MeHg}$ flux, and odonates will play a greater role as a biovector of $\mathrm{Hg}$ to terrestrial consumers. More work is needed to determine the magnitude of insect-mediated $\mathrm{MeHg}$ flux from systems with and without fish and how the effects of fish on $\mathrm{MeHg}$ flux vary with fish species. Given the prominence of small ponds on the landscape and the widespread nature of atmospheric $\mathrm{Hg}$ deposition, the impact of small ponds on terrestrial $\mathrm{Hg}$ cycling is probably quite significant.

\section{ASSOCIATED CONTENT}

\section{S Supporting Information}

Additional information as noted in the text. This material is available free of charge via the Internet at http://pubs.acs.org.

\section{AUTHOR INFORMATION}

\section{Corresponding Author}

*E-mail: m.m.chumchal@tcu.edu.

\section{Notes}

The authors declare no competing financial interest.

\section{ACKNOWLEDGMENTS}

We thank Tony Burgess, Alden Park, Cyrus Elahi, Amanda Hale, Weston Nowlin, Jesse Becker, Gabrielle Timmins, and Gary Cocke for assistance. This research was supported by Nextera Energy Resources LLC, a Texas Christian University (TCU) Research and Creative Activities Fund Grant, a Society of Environmental Toxicology and Chemistry South-Central Regional Chapter Funding to Aid Interdisciplinary Research Grant, the TCU Biology Department Adkin's Fund, and the TCU Biology Department. We are grateful to Steven Barden and Arms Bait Company for stocking fish and the Tarrant Regional Water District for providing access to the ponds for this research.

\section{REFERENCES}

(1) Scheuhammer, A. M.; Meyer, M. W.; Sandheinrich, M. B.; Murray, M. W. Effects of environmental methylmercury on the health of wild birds, mammals, and fish. Ambio 2007, 36, 12-18.

(2) Selin, N. E. Global biogeochemical cycling of mercury: a review. Annu. Rev. Environ. Resour. 2009, 34, 43-63.

(3) Wada, H.; Yates, D. E.; Evers, D. C.; Taylor, R. J.; Hopkins, W. A. Tissue mercury concentrations and adrenocortical responses of female big brown bats (Eptesicus fuscus) near a contaminated river. Ecotoxicology 2010, 19, 1277-1284.

(4) Cristol, D. A.; Brasso, R. L.; Condon, A. M.; Fovargue, R. E.; Friedman, S. L.; Hallinger, K. K.; Monroe, A. P.; White, A. E. The movement of aquatic mercury through terrestrial food webs. Science 2008, 320, 335-335.

(5) Jackson, A. K.; Evers, D. C.; Folsom, S. B.; Condon, A. M.; Diener, J.; Goodrick, L. F.; McGann, A. J.; Schmerfeld, J.; Cristol, D. A. Mercury exposure in terrestrial birds far downstream of an historical point source. Environ. Pollut. 2011, 159, 3302-3308.

(6) Gerrard, P. M.; St Louis, V. L. The effects of experimental reservoir creation on the bioaccumulation of methylmercury and reproductive success of tree swallows (Tachycineta bicolor). Environ. Sci. Technol. 2001, 35, 1329-1338.

(7) Walters, D. M.; Fritz, K. M.; Otter, R. R. The dark side of subsidies: adult stream insects export organic contaminants to riparian predators. Ecol. Appl. 2008, 18, 1835-1841.

(8) Walters, D. M.; Mills, M. A.; Fritz, K. M.; Raikow, D. F. Spidermediated flux of $\mathrm{PCBs}$ from contaminated sediments to terrestrial ecosystems and potential risks to arachnivorous birds. Environ. Sci. Technol. 2010, 44, 2849-2856.
(9) Raikow, D. F.; Walters, D. M.; Fritz, K. M.; Mills, M. A. The distance that contaminated aquatic subsidies extend into lake riparian zones. Ecol. Appl. 2011, 21, 983-990.

(10) Menzie, C. Potential significance of insects in the removal of contaminants from aquatic systems. Water, Air, Soil Pollut. 1980, 13, 473-479.

(11) Vander Zanden, M. J.; Gratton, C. Blowin' in the wind: Reciprocal airborne carbon fluxes between lakes and land. Can. J. Fish. Aquat. Sci. 2011, 68, 170-182.

(12) Gratton, C.; Vander Zanden, M. J. Flux of aquatic insect productivity to land: comparison of lentic and lotic ecosystems. Ecology 2009, 90, 2689-2699.

(13) Gratton, C.; Donaldson, J.; Vander Zanden, M. J. Ecosystem linkages between lakes and the surrounding terrestrial landscape in northeast Iceland. Ecosystems 2008, 11, 764-774.

(14) Nakano, S.; Murakami, M. Reciprocal subsidies: dynamic interdependence between terrestrial and aquatic food webs. Proc. Natl. Acad. Sci. U.S.A. 2001, 98, 166-170.

(15) Baxter, C. V.; Fausch, K. D.; Saunders, C. W. Tangled webs: reciprocal flows of invertebrate prey link streams and riparian zones. Freshwater Biol. 2005, 50, 201-220.

(16) Paetzold, A.; Smith, M.; Warren, P. H.; Maltby, L. Environmental impact propagated by cross-system subsidy: chronic stream pollution controls riparian spider populations. Ecology 2011, 92, $1711-1716$

(17) Sullivan, S. M. P.; Rodewald, A. D. In a state of flux: the energetic pathways that move contaminants from aquatic to terrestrial environments. Environ. Toxicol. Chem. 2012, 31, 1175-1183.

(18) Jones, T. A.; Chumchal, M. M.; Drenner, R. W.; Nowlin, W. H.; Timmins, G. A. Bottom-up nutrient and top-down fish impacts on contaminant flux from aquatic ecosystems. Environ. Toxicol. Chem. 2013, in press.

(19) McCarty, J. Aquatic community characteristics influence the foraging patterns of tree swallows. Condor 1997, 99, 210-213.

(20) Greig, H. S.; Kratina, P.; Thompson, P. L.; Palen, W. J.; Richardson, J. S.; Shurin, J. B. Warming, eutrophication, and predator loss amplify subsidies between aquatic and terrestrial ecosystems. Global Change Biol. 2012, 18, 504-514.

(21) Henderson, B. L.; Chumchal, M. M.; Drenner, R. W.; Deng, Y.; Diaz, P.; Nowlin, W. H. Effects of fish on mercury contamination of macroinvertebrate communities of grassland ponds. Environ. Toxicol. Chem. 2012, 31, 870-876.

(22) Epanchin, P. N.; Knapp, R. A.; Lawler, S. P. Nonnative trout impact an alpine-nesting bird by altering aquatic-insect subsidies. Ecology 2010, 91, 2406-2415.

(23) Wesner, J. S. Aquatic predation alters a terrestrial prey subsidy. Ecology 2010, 91, 1435-1444.

(24) Akamatsu, F.; Toda, H. Aquatic subsidies transport anthropogenic nitrogen to riparian spiders. Environ. Pollut. 2011, 159, 13901397.

(25) Williams, D.; Ambrose, L.; Browning, L. Trophic dynamics of 2 sympatric species of riparian spider (Araneae, Tetragnathidae). Can. J. Zool. 1995, 73, 1545-1553.

(26) Gillespie, R. G. The mechanism of habitat selection in the longjawed orb-weaving spider Tetragnatha-elongata (Araneae, Tetragnathidae). J. Arachnol. 1987, 15, 81-90.

(27) Collier, K. J.; Bury, S.; Gibbs, M. A stable isotope study of linkages between stream and terrestrial food webs through spider predation. Freshwater Biol. 2002, 47, 1651-1659.

(28) Lee, D. S. Atlas of North American Freshwater Fishes; North Carolina State Museum of Natural History: Raleigh, NC, 1980; pp 591-592.

(29) O'Brien, W. J. The predator-prey interaction of planktivorous fish and zooplankton: recent research with planktivorous fish and their zooplankton prey shows the evolutionary thrust and parry of the predator-prey relationship. Am. Sci. 1979, 67, 572-581.

(30) Howick, G. L.; O'Brien, W. J. Piscivorous feeding behavior of largemouth bass: an experimental-analysis. Trans. Am. Fish. Soc. 1983, $112,508-516$. 
(31) Olson, M. H. Ontogenetic niche shifts in largemouth bass: variability and consequences for first-year growth. Ecology 1996, 77, $179-190$.

(32) Gilinsky, E. The role of fish predation and spatial heterogeneity in determining benthic community structure. Ecology 1984, 65, 455468.

(33) Mittelbach, G. G. Predation and resource partitioning in two sunfishes (Centrarchidae). Ecology 1984, 65, 499-513.

(34) Vander Zanden, M. J.; Vadeboncoeur, Y. Fishes as integrators of benthic and pelagic food webs in lakes. Ecology 2002, 83, 2152-2161.

(35) Jackson, B.; Taylor, V.; Baker, R. A.; Miller, E. Low-level mercury speciation in freshwaters by isotope dilution GC-ICP-MS. Environ. Sci. Technol. 2009, 43, 2463-2469.

(36) Taylor, V. F.; Jackson, B. P.; Chen, C. Y. Mercury speciation and total trace element determination of low-biomass biological samples. Anal. Bioanal. Chem. 2008, 392, 1283-1290.

(37) Hammerschmidt, C. R.; Fitzgerald, W. F. Methylmercury in mosquitoes related to atmospheric mercury deposition and contamination. Environ. Sci. Technol. 2005, 39, 3034-3039.

(38) Maxwell, S. E.; Delaney, H. D. Designing Experiments and Analyzing Data: A Model Comparison Perspective; Lawrence Erlbaum Associates: Mahwah, NJ, 2004.

(39) Munthe, J.; Bodaly, R. A.; Branfireun, B. A.; Driscoll, C. T.; Gilmour, C. C.; Harris, R.; Horvat, M.; Lucotte, M.; Malm, O. Recovery of mercury-contaminated fisheries. Ambio 2007, 36, 33-44. (40) Hammerschmidt, C. R.; Fitzgerald, W. F. Methylmercury in freshwater fish linked to atmospheric mercury deposition. Environ. Sci. Technol. 2006, 40, 7764-7770.

(41) Drenner, R. W.; Chumchal, M. M.; Wente, S. P.; McGuire, M.; Drenner, S. M. Landscape-level patterns of mercury contamination of fish in North Texas. Environ. Toxicol. Chem. 2011, 30, 2041-2045.

(42) Driscoll, C. T.; Han, Y.; Chen, C. Y.; Evers, D. C.; Lambert, K. F.; Holsen, T. M.; Kamman, N. C.; Munson, R. K. Mercury contamination in forest and freshwater ecosystems in the Northeastern United States. Bioscience 2007, 57, 17-28.

(43) Evers, D. C.; Han, Y.; Driscoll, C. T.; Kamman, N. C.; Goodale, M. W.; Lambert, K. F.; Holsen, T. M.; Chen, C. Y.; Clair, T. A.; Butler, T. Biological mercury hotspots in the northeastern United States and southeastern Canada. Bioscience 2007, 57, 29-43.

(44) Batzer, D. P.; Wissinger, S. A. Ecology of insect communities in nontidal wetlands. Annu. Rev. Entomol. 1996, 41, 75-100.

(45) Wellborn, G. A.; Skelly, D. K.; Werner, E. E. Mechanisms creating community structure across a freshwater habitat gradient. Annu. Rev. Ecol. Syst. 1996, 27, 337-363.

(46) Downing, J. A. Emerging global role of small lakes and ponds: little things mean a lot. Limnetica 2010, 29, 9-23.

(47) Downing, J. A.; Prairie, Y. T.; Cole, J. J.; Duarte, C. M.; Tranvik, L. J.; Striegl, R. G.; McDowell, W. H.; Kortelainen, P.; Caraco, N. F.; Melack, J. M.; Middelburg, J. J. The global abundance and size distribution of lakes, ponds, and impoundments. Limnol. Oceanogr. 2006, 51, 2388-2397.

(48) Scheffer, M.; Van Geest, G. J.; Zimmer, K.; Jeppesen, E.; Søndergaard, M.; Butler, M. G.; Hanson, M. A.; Declerck, S.; De Meester, L. Small habitat size and isolation can promote species richness: second-order effects on biodiversity in shallow lakes and ponds. Oikos 2006, 112, 227-231.

(49) Rahel, F. J. Biogeographic barriers, connectivity and homogenization of freshwater faunas: it's a small world after all. Freshwater Biol. 2007, 52, 696-710. 